\title{
Return Sponsorships in the EU's New Pact on Migration and Asylum: High Stakes, Low Gains
}

\author{
Olivia Sundberg Diez \\ Policy and Advocacy Advisor, International Rescue Committee, \\ Brussels, Belgium \\ Former Policy Analyst, European Policy Centre (EPC), Brussels, Belgium \\ Olivia.sundberg@rescue.org
}

Florian Trauner| ORCID: 0000-0001-5044-6818

Jean Monnet Chair, Brussels School of Governance, Vrije Universiteit Brussel, Brussels, Belgium

Florian.Trauner@vub.be

\author{
Marie De Somer \\ Head of the Migration and Diversity Programme, \\ European Policy Centre (E PC), Brussels, Belgium \\ Visiting Professor at the KU Leuven, Leuven, Belgium \\ and at Sciences Po, Paris, France \\ M.desomer@epc.eu / Marie.Desomer@kuleuven.be
}

\begin{abstract}
The concept of 'return sponsorships' is central to the European Commission's New Pact on Migration and Asylum, and its ambition to deliver a "fresh start on migration". Enabling a system of mandatory yet flexible solidarity, the concept is designed to overcome the opposing viewpoints that have long marked political discussions over responsibility-sharing within Europe. This article critically considers whether return sponsorships can work in practice. It identifies three challenges. First, the proposal's envisioned solidarity measures lack predictability and tangibility. Second, return sponsorships will create new vulnerabilities for those issued return orders. Third, the mechanism is informed by the improbable assumption that more conditionalities vis-à-vis third countries will substantially increase the EU's return rate. Overall, the Commission is taking a considerable risk. The return sponsorship concept will likely prolong the polarised discussions among Member States and provide only modest support to countries at the EU's external border.




\section{Keywords}

New Pact on Migration and Asylum - EU Asylum Law - Return Policies - Return Sponsorship - EU external relations

A first version of this text was originally elaborated to inform a Discussion Paper on the subject by the European Policy Centre (EPC). The authors are thankful for the comments and feedback provided in this context and the reviewers of the European Journal of Migration and Law. The financial support of the Erasmus+ Programme is gratefully acknowledged (Project 621045 EPP-1-202O-1-BE-EPPJMO-CHAIR).

\section{Introduction}

On 23 September 2020, the European Commission unveiled its longawaited New Pact on Migration and Asylum. Aiming to mark a "fresh start on migration", the Commission put forward a complex package of five new legislative proposals, three recommendations and one guidance, with further legislative initiatives to follow in the coming year. ${ }^{1}$

Many ideas in the proposals build on existing policies or rehearse earlier ideas for policy reform, prompting some commentators to brand the Pact as "old wine in new bottles". 2 This is not true for all proposals, however. Arguably, one of the most remarkable and novel among them is the Commission's idea of setting up a mechanism of 'return sponsorships'. This mechanism is also part of the Pact's larger and central ambition to establish a new system of intra-EU solidarity on migration.

As is well known, the previous EU legislature failed to overcome the political cleavages around intra-EU solidarity in the area of asylum and migration. ${ }^{3}$ This failure, in turn, also led to the demise of the larger attempts at structurally reforming the Common European Asylum System (CEAS), which had been

1 European Commission, 2020, A fresh start on migration: Building confidence and striking a new balance between responsibility and solidarity, Brussels: EC, 23 September 2020.

2 The Irish Times, The Irish Times view on the EU migration plan: old wine in a new bottle (23 September 2020). Available at: https://www.irishtimes.com/opinion/editorial/the -irish-times-view-on-the-eu-migration-plan-old-wine-in-a-new-bottle-1.4362568.

3 Zaun, N., 2018, States as Gatekeepers in EU Asylum Politics. Explaining the Non-adoption of a Refugee Quota System, Journal of Common Market Studies, 56 (1), pp. 44-62. 
on the table since $2016 .{ }^{4}$ Unsurprisingly, new ways of thinking about intra-EU solidarity were therefore placed front and centre in the preparation of the New Pact. Adopting what commentators have described as a 'realpolitik approach', the Commission sought, as a priority, to overcome the opposing viewpoints between those advocating for mandatory solidarity mechanisms in the form of relocations of asylum seekers from EU border states to other EU states, and those manifestly opposing any form of solidarity premised on such mandatory relocations. ${ }^{6}$

The former view has been advanced most notably by Southern Member States who hold that a "mandatory system providing for a fair and rapid distribution of asylum seekers" is necessary for any reform of the CEAS to be "fair and sustainable." ${ }^{7}$ By contrast, the latter view has, over the past years, been most vocally defended by the four Eastern Visegrád states (Hungary, Poland, the Czech Republic and Slovakia) as well as Austria and Denmark. These states argue that intra-EU solidarity should be organised in a "flexible" manner, enabling them to decide on specific forms of solidarity contributions in line with their experience and potential. ${ }^{8}$ The positions of Northern and Western European states have varied over time and by country. Some, such as Germany, have repeatedly advocated for mandatory relocations, whereas France has been open to more flexibility in terms of contributions. ${ }^{9}$

The New Pact's proposal for a compromise between these opposing views of mandatory and flexible forms of solidarity is premised on the idea of providing

4 European Commission, 2016, Towards a sustainable and fair Common European Asylum System, Brussels: EC, 4 May 2016.

5 Thym, D., 2020, European Realpolitik: Legislative Uncertainties and Operational Pitfalls of the 'New' Pact on Migration and Asylum, Immigration and Asylum Law and Policy Blog, 28 September 2020. Available at: http://eumigrationlawblog.eu/european-realpolitik -legislative-uncertainties-und-operational-pitfalls-of-the-new-pact-on-migration-and -asylum/.

6 Beirens, H., 2020, The EU Pact on Migration and Asylum - A Bold Move to Avoid the Abyss?, Commentary, Brussels: Migration Policy Institute.

7 Cyprus, Greece, Spain, Italy and Malta, 2020, Non-paper on the reform of the Common European Asylum System in the perspective of an EU migration and asylum policy. Available at: https://www.statewatch.org/media/documents/news/2020/apr/eu-ceas-cy-el-es-it-mt-non -paper-4-2o.pdf.

8 Gotev, G., 2016, 'Flexible solidarity' becomes new tool in response to refugee crisis, Euractiv, 19 September 2016. Available at: https://www.euractiv.com/section/justice-home-affairs/ news/flexible-solidarity-becomes-new-tool-in-response-to-refugee-crisis/.

9 Mercator Dialogue on Asylum and Migration, 2020, 2020 MEDAM Assessment Report on Asylum and Migration Policies in Europe, Kiel: Kiel Institute for the World Economy, pp. 17, 19-21. 
for mandatory, flexible solidarity. In short, this implies that states would be mandated to showcase solidarity in situations of migration pressure but have a degree of flexibility as to how they showcase such solidarity.

More specifically, and as the proposal for an Asylum and Migration Management Regulation (AMMR) sets out, once a state is faced with migratory pressure (including a risk thereof), other Member States will be mandated to showcase solidarity..$^{10}$ Member states can, however, choose whether to contribute by (i) relocating asylum seekers, (ii) supporting the return of migrants without permission to remain through return sponsorships, (iii) through financial or operational assistance (with some caveats), or a combination of these. ${ }^{11}$ Under the return sponsorship option, a Member State would commit to carry out (some of) the necessary activities to return individually identified third-country nationals from the state under migratory pressure. Should these efforts fail after 8 months (or 4 months in times of crisis), sponsoring states would need to transfer the returnee(s) to their own territories to continue the return process from there. ${ }^{12}$

Some corrective mechanisms exist if states' contributions fall short or disproportionately favour operational support. ${ }^{13}$ In such instances, the Commission can require that sponsoring states either relocate or return $50 \%$ of the share of persons they were allocated. However, and as the Commission has not failed to stress, ${ }^{14}$ states would never be mandated to relocate asylum seekers: contributing exclusively through returns would always remain an option. The return sponsorship mechanism, and particularly to the extent that it functions as the alternative to mandatory relocations, can therefore be placed at the heart of the new ideas around mandatory flexible solidarity.

The return sponsorship mechanism is, in addition, also connected to broader attempts to increase effective returns. This objective is firmly embedded

10 European Commission, 2020, Proposal for a Regulation of the European Parliament and of the Council on asylum and migration management and amending Council Directive (EC) 2003/1og and the proposed Regulation (EU) XXX/XXX [Asylum and Migration Fund], $\operatorname{COM}(2020) 610$ final, Brussels.

11 Ibid., Art. 45 .

12 Ibid., Art. 55.

13 Ibid., Arts. 52(4), 53(2). For a detailed discussion on the solidarity mechanism, including its corrective elements, see Maiani, F., 2020, A 'Fresh Start' or One More Clunker? Dublin and Solidarity in the New Pact, Immigration and Asylum Law and Policy Blog, 20 October 2020. Available at: http://eumigrationlawblog.eu/a-fresh-start-or-one-more -clunker-dublin-and-solidarity-in-the-new-pact/.

14 Schinas, M., 2020, Speech by Vice-President Schinas on the New Pact on Migration and Asylum, Brussels: European Commission, 23 September. Available at: https://ec.europa .eu/commission/presscorner/detail/en/SPEECH_2O_1736. 
throughout the Pact's proposals, including efforts to link (negative) asylum and return decisions, the establishment of a High-Level Network for Return, and a Strategy on Voluntary Returns and Reintegration released in April 2021. In that way, the Commission has also sought to capitalize on the heightened political attention that has gone out to this specific policy area over the past years. ${ }^{15}$ More generally, increasing returns and improving readmission cooperation with third states are areas around which Member States' interests and priorities tend to more easily converge. ${ }^{16}$ Notably, this also includes the priorities of states, like the Visegrád four, that oppose mandatory relocations but have called for stronger control-oriented policies instead, including large-scale return operations away from Europe. ${ }^{17}$ Even if these states continue to ideologically oppose mandatory relocations, they may be willing to contribute to EU-wide return policies. ${ }^{18}$

In short, the political background and logic of the return sponsorship mechanism are easy to understand. Its operational added value, however, is harder to assess. As commentators have already highlighted, the merit of the return sponsorship proposal, or even the New Pact as a whole, is more likely to be found in its politically pragmatic approach. The practical or operational considerations appear to have taken a backseat. ${ }^{19}$ Such considerations remain crucial, however. Of course, having an operationally airtight proposal (if that ever exists) is pointless when its political feasibility, and hence its prospects of becoming reality, are non-existent. The converse also holds. A politically

15 Council of the European Union, 2019, Policies and Tools to Enhance Readmission Cooperation - Presidency Discussion Paper, 1319o/19, Brussels: Council of the European Union. Available at: https://www.statewatch.org/media/documents/news/2019/nov/eu -council-readmission-cooperation-1319o-19.pdf. See also: Sundberg Diez, O., 2019, Diminishing safeguards, increasing returns: Non-refoulement gaps in the EU return and readmission system, Brussels: European Policy Centre, pp. 6-7.

16 Hadj Abdou, L., 2021, From the Migration Crisis to the New Pact on Migration and Asylum: The Status Quo Problem, 1 February 2021, BRIDge Network Working Paper 11. Dublin: Dublin City University. Available at: https://ssrn.com/abstract=3786906 or http://dx.doi .org/10.2139/ssm.37869o6.

17 Szalai, M., Csornai, Z. and Garai, N., 2017, V4 Migration Policy: Conflicting Narratives and Interpretative Frameworks, Barcelona: Сіров.

18 Tsourdi, L., 2021, Reforming the EU asylum policy: unilateralism, 'coalitions of the willing', and the new pact on migration and asylum, 22 January 2021, Maastricht University Blog. Available at: https://www.maastrichtuniversity.nl/blog/2021/o1/reforming-eu-asylum -policy-unilateralism-\%E2\%8०\%98coalitions-willing\%E2\%8०\%99-and-new-pact -migration.

19 Maiani, 2020, op.cit. 
sound proposal that will lead to operational difficulties is likely to bring us full circle again. ${ }^{20}$

The purpose of this article is to scrutinize the return sponsorship's operational merit and review its potential to deliver the much-needed solidarity mechanism that EU migration policies lack, whilst providing a valuable addition to current EU return policies. Many of the details of the proposed mechanism have been left open in the Commission's proposals in order to allow for room for manoeuvre in the inter-institutional negotiations. As Home Affairs Commissioner Ylva Johansson noted, whereas "the devil is in the detail", the same holds for the opportunities to find political compromises. ${ }^{21}$ While the proposal's final articles will still be defined by the negotiations, its broad lines nevertheless already provide material for reviewing different scenarios, as well as potential future difficulties, that could result from its operationalisation.

Our analysis is informed by a review of earlier implementation difficulties in the EU's asylum and returns acquis. These include, amongst others, difficulties stemming from overly administration- and coordination-heavy procedures; issues related to a lack of trust among Member States in implementing common EU policies; difficulties in ensuring that EU migration policy measures are implemented in line with higher principles of EU law, notably human rights standards; as well as problems stemming from a misalignment between the EU's return and readmission agenda and broader (e.g., security-oriented) foreign affairs objectives. We do not analyse the concept's implications for other international organisations, but acknowledge that return sponsorships may potentially compromise the "internationally agreed and legally binding human rights standards" agreed within the United Nations Global Compact for Safe, Orderly and Regular Migration and the Global Compact on Refugees. ${ }^{22}$ Our analysis is further built upon an investigation of primary and secondary sources, including Member States' position papers and Council

20 It bears noting that negotiations on the return sponsorship proposal up to early 2021 have continued to be met with divisions among Member States. Questions such as the primacy of relocations, the breadth of the catalogue of possible solidarity measures, as well as the timeline and flexibility pertaining to the transfer requirement continue to firmly divide Southern and Eastern European states. See Sundberg Diez, O. and Trauner, F., 2020, EU return sponsorships: High stakes, low gains?, Brussels: European Policy Centre, pp. 6-7.

21 Comment by Ylva Johansson, European Commissioner for Home Affairs, during 'The New Pact on Migration and Asylum: A fresh start?', online event as part of the Mercator Dialogue on Asylum and Migration project on 13 November 2020, Brussels: European Policy Centre. Available at: https://www.youtube.com/watch?v=bIvkdyKkMQY.

22 See Vosyliute, L., 2021, When principles are compromised: EU return sponsorship in light of the UN Global Compacts, ASILE Contribution, Brussels: CEPS. 
and Commission documents, as well as five interviews with key stakeholders of the European Commission, the Council of the EU and civil society organisations.

Our article is structured around three core questions. First, will the proposal be able to provide tangible support to Member States at the EU's external border? Second, is the instrument a suitable addition to EU return policy, capable of navigating the complexity and human rights sensitivity of returns? Third, are the proposed measures in the area of return, including an increased use of conditionality, likely to secure the New Pact's wider objective of increasing returns? These three questions form, respectively, the subject of the next three subsections. Crosscutting all these questions is the overarching research interest: can this concept work in practice?

The article highlights three key challenges for the Commission's concept. These include, first, the lacking predictability and tangibility of support provided by the mechanism to EU frontline states. Second, the proposal may create new vulnerabilities for migrants issued return orders. Third, EU institutions and Member States should be wary of inflated expectations regarding the likely impact of using conditionality in the area of returns. Addressing these challenges during and after the negotiations will, in our view, be critical for the proposal's ability to deliver on the ground.

\section{Can Return Sponsorships Provide Tangible Solidarity} to EU Border States?

The solidarity mechanism proposed by the Commission aims to alleviate the pressure on Member States of first arrival. However, it does not fully remove this pressure. The key tenets of the Dublin Regulation would remain in place. ${ }^{23}$ Accordingly, responsibility for newly arriving asylum seekers continues, first and foremost, to be allocated to the first country of entry. In addition, according to the New Pact's further proposals, even before a relocation or a return sponsorship process kicks in, host countries are responsible for migrants' preentry screening, conducting a preliminary assessment of responsibility, and assessing all asylum applications channelled into the border procedure. They are also responsible for conducting sponsored returns during the first eight months. Therefore, the Commission's proposals do not fundamentally change the way that 'responsibility' is organised. Several elements would in fact expand

23 On the continuity of the Dublin regime, see the section 'Dublin is dead, long live Dublin' of the analysis of Thym 2020, op.cit. 
the duties and responsibilities of EU border states. ${ }^{24}$ Against this background, the new solidarity mechanisms should rather be understood as an exceptional insurance scheme for countries facing high migratory pressure. ${ }^{25}$

A critical first question is therefore whether the instrument can sufficiently support Member States on the EU's border, which face greater numbers of spontaneous arrivals. The proposed solidarity mechanism, and particularly the concept of return sponsorship, involve careful trade-offs between flexibility and predictability. This section explores whether these new elements of flexibility can be provided without undermining the system's overall ability to function and provide the required 'insurance' to states under pressure.

\subsection{Flexibility Versus Predictability}

The solidarity mechanism involves a large degree of choice and flexibility for contributing states. This flexibility comes at the expense of predictability and certainty for benefiting states, precluding them from planning, allocating resources and building capacity based on the scale, kind, and timeliness of the support they expect or have been guaranteed to receive.

Contributing states would, first, be able to choose the form of their support (relocations, return sponsorships, or operational support). As highlighted in the introduction, the possible enforced corrections remain limited as states can always opt for either relocations or returns. The practical elements of this support, too, remain open, although it must meet a concrete need of the benefiting state. For example, return sponsors could facilitate returns through activities such as counselling on returns, providing financial or logistical support towards voluntary return and reintegration, leading or supporting readmission negotiations with third countries, or organising return flights. ${ }^{26}$

It is unclear how each Member State will choose to contribute, or what kinds of contributions will be most needed at different moments. However, experience suggests a limited political will to contribute to relocations at the scale of actual needs. Two voluntary, ad hoc relocation mechanisms have been established in recent years: the Malta Declaration of September 2019, aimed

24 Mercator Dialogue on Asylum and Migration (2021), 2021 MEDAM Assessment Report on Asylum and Migration Policies in Europe, Kiel: Kiel Institute for the World Economy, pp. 22-27. See also Hadj Abdou, L. (2021), From the Migration Crisis to the New Pact on Migration and Asylum: The Status Quo Problem', BRIDGE Network Working Paper 11, Dublin: Dublin City University.

25 Maiani 2020, op.cit.

26 European Commission, 2020, op.cit., Art. 55(4). 
at asylum seekers rescued at sea and disembarking in Malta or Italy; ${ }^{27}$ and the Commission's scheme to voluntarily distribute unaccompanied children from overcrowded camps in the Greek islands from March 2020 onwards. While they have provided valuable support to many asylum seekers in need and states under pressure, both of these schemes have failed to secure the support of more than a handful of Member States, and this after considerable pressure and delays. ${ }^{28}$

Compared with relocations, return sponsorships may be more attractive to Member States as they will only lead to a delayed or no transfer of migrants to their territories. There is a risk, therefore, that Member States will disproportionately favour contributing through returns, even if it is not the most needed or appropriate method of alleviating pressure in a certain case. Moreover, the introduction of returns as an option for solidarity risks shifting the preferences of Member States that participate in existing ad-hoc relocation schemes. It may weaken the (modest) momentum that has been achieved for intra-EU relocations.

Similarly, states would enjoy flexibility when choosing the nationalities whose returns they wish to sponsor. Certain states in the EU's eastern and south-eastern neighbourhood are known to willingly facilitate the readmission of their nationals from Europe (e.g. Albania, Serbia, Ukraine, Russia, Georgia). Other countries of origin have low rates of effective returns (e.g. Mali, Guinea, Syria, Afghanistan, Bangladesh, Algeria). ${ }^{29}$ EU Member States may consider it rational to opt for nationalities that are known to be returned more straightforwardly. Questions as to how this 'competition' for sponsoring certain nationalities will be determined, and who will remain responsible for those not chosen, are left open.

27 See Germany, France, Italy and Malta, 2019, Joint Declaration of Intent on a Controlled Emergency Procedure - Voluntary Commitments by Member States for a Predictable Temporary Solidarity Mechanism, Valletta: European Sources Online.

28 Of the over 2,0oo relocations which have been conducted from Italy and Malta since January 2019, most have been to France and Germany. Similarly, over half of the 2,000 vulnerable asylum seekers and refugees relocated from Greece in 2020 were transferred to Germany. Whereas 16 Member States have so far pledged relocations under this scheme, these came only after substantial delays and often with limited commitments. See Mercator Dialogue on Asylum and Migration, 2020, op.cit., p. 19; International Organisation for Migration, 2020, Voluntary Scheme for the Relocation from Greece to other European Countries, 17 December, Grand-Saconnex; European Commission, 2020, Relocation of unaccompanied children from Greece to Portugal and to Finland - Questions and answers, Brussels: EC.

29 Mercator Dialogue on Asylum and Migration 2020, op.cit., p. 23. 
To ensure that states' choice of mode of contribution effectively meets the expressed needs of states of first arrival, the Commission will need to establish a complicated matching exercise. In the case of return sponsorships, Member State authorities will need to liaise closely with each other, on a case-bycase basis, to determine (i) what forms of support towards return would add value and be most appropriate, as well as (ii) ensuring the implementation of this support.

This setup risks descending into time-consuming, politically sensitive, and ad hoc negotiations, which may fail to provide prompt support for EU border states. States in need of solidarity are likely to bear most of the responsibility for taking care of migrants in the meantime. A new EU Return Coordinator would be involved in and help to coordinate this dialogue. However, bringing together different interests and resolving conflicts are no small tasks for the Coordinator. They are substantial expectations for a position that is yet to be created, and whose level of seniority within the Commission is yet to be determined. ${ }^{30}$ If the process governing the return sponsorship mechanism collapses into manifold, prolonged negotiations, cooperation-reluctant Member States may find many opportunities to undermine the solidarity mechanism and lower their actual contributions.

Lastly, in this context, the enforcement prospects for the new solidarity proposal merit attention. No targeted incentives, sanctions or enforcement tools appear to be envisioned in case a Member State fails to comply with the solidarity mechanism, in its entirety or in part. Instead, the Commission appears to rely on infringement procedures. These tend to be lengthy and may not be enough to secure a state's compliance. ${ }^{31}$ Furthermore, the Commission tends to be hesitant to trigger infringement procedures in politically sensitive areas. The solidarity mechanism may create conflicts of interest that further complicate their use. Given the Commission's reliance on states' willingness to contribute to solidarity efforts voluntarily, such as through the Solidarity Forum, it will likely be hesitant to sour relations by launching infringement procedures over other aspects of the solidarity mechanism. Considering the significant

30 Interview with European Commission official, October 2020.

31 For example, on 2 April 2020, the Court of Justice of the EU ruled against Poland, Hungary and the Czech Republic for failing to take part in the 2015 emergency relocation mechanism. The ruling came almost five years after the original decision and long after the end of the relocation scheme. Its practical effects were limited. The ruling did not change the position of these three states, which continued to refuse relocating asylum seekers. 
gaps in the implementation of existing asylum legislation, there is every risk that the Pact's more politically sensitive proposals may become a dead letter. ${ }^{32}$

\subsection{Do Sponsors Have the Political Will and Capacity to Contribute?}

When preparing the New Pact, the Commission drafted a matrix to determine which Member States could sponsor which nationalities. ${ }^{33}$ It found that almost all Member States could contribute to the returns of some key nationalities, based on returns they had already successfully conducted in the past. On this basis, Commission officials argued that the proposal's in-built flexibility would not undermine its functioning.

However, this argument is optimistic. Firstly, even if almost all states do have some diplomatic links to countries of migrants' origin, some have far stronger bilateral relations than others. Over $70 \%$ of total bilateral readmission agreements concluded between EU and African countries are covered by France, Italy and Spain. ${ }^{34}$ This raises questions over whether the EU states most likely to engage in return sponsorships can achieve sufficient returns. Hungary or the Czech Republic, for example, have rates of effective returns that are well below the European average. ${ }^{35}$ They do not have particular diplomatic clout nor (historically) close relations with key countries of origin. There are few obvious reasons to assume that they can incentivise third countries to cooperate more on readmission.

Such EU countries with weak diplomatic leverage may seek to contribute through other means (e.g. financial or operational support). Nevertheless, they are poorly placed to address bilateral readmission negotiations or the implementation of EU readmission agreements, which are a key bottleneck to successful returns. The proposal is still open on whether various Member States could 'share' an individual's return sponsorship according to their strengths. For example, one state may fund flights or voluntary return and reintegration programmes. Another may lead readmission negotiations. This could provide

32 See e.g. Goldner Lang, I., 2020, No Solidarity without Loyalty: Why Member States Violate EU Migration and Asylum Law and What Can Be Done?, European Journal of Migration and Law, 22 (1), pp. 35-59.

33 Interview with European Commission official, October 2020. This matrix is not publicly available.

34 Cassarino, J.-P., 2020, Readmission, Visa Policy and the 'Return Sponsorship' Puzzle in the New Pact on Migration and Asylum, ADiM Blog, pp. $5^{-6}$.

35 E.g. between 2017 and 2019, the Czech Republic had an effective return rate of $13 \%$. Hungary had a rate of $27 \%$, while also conducting small absolute numbers of returns. See Eurostat, 2020, Third country nationals returned following an order to leave - annual data (rounded)[migr_eirtn], Luxembourg: Eurostat; Eurostat, 2020, Third country nationals ordered to leave - annual data (rounded)[migr_eiord], Luxembourg: Eurostat. 
an answer to certain Member States' challenging lack of capacity. However, it would entail a greater need for coordination and may bring up other discussions over which state has the primary responsibility.

Secondly, it is also uncertain whether the EU countries with stronger diplomatic links with key countries of origin will be willing to leverage them for a common European objective. Readmission issues tend to affect bilateral relations negatively. ${ }^{36}$ Nevertheless, this is a key demand of the return sponsorship concept: Member States are expected to put their privileged bilateral relationships under pressure, to return migrants from other EU states. Lastly, it remains to be seen whether third countries will be receptive to a Member State that is their historical partner negotiating on behalf of another state or a group of states.

\subsection{Brokering and Trust}

To function effectively, return sponsorships would rely on trust and cooperation among Member States, as well as between states and the Commission. To begin with, as it stands, the proposal envisions a strong role for the European Commission in determining when and how the solidarity mechanisms would come into play. The Commission grants itself the role of establishing when a Member State is confronted with recurring arrivals, migratory pressure, the risk thereof, or a crisis. Its decisions will be based on a "holistic qualitative assessment" which considers a broad range of factors, which are purposely left vague to retain the assessment's flexibility. ${ }^{37}$ This discretion also applies when determining how various contributions relate to each other. For example, how many returns equal the financing of a new detention centre or capacitybuilding support for third countries' border guards?

The degree of flexibility and discretion granted to the Commission complicates predicting how the mechanism will work in practice. The Commission will have to be seen as an honest, trusted and impartial broker among Member States. ${ }^{38}$ Conversely, if this role is not preserved - i.e., if the Commission's discretionary and coordinating powers do not survive the Council negotiations which is a likely outcome according to some, the AMMR's solidarity mechanism may come to resemble the ad hoc bargaining that has characterised relocation

36 See e.g. Cassarino, J.-P., 2010, Dealing with unbalanced reciprocities: Cooperation on Readmission and Implications, in: J.-P. Cassarino (ed.), Unbalanced Reciprocities: Cooperation on Readmission in the Euro-Mediterranean Area, Washington DC: Middle East Institute, Ch. 1.

37 European Commission 2020, op.cit., p. 12 and Art. 53(3)-(4).

38 Woollard, C., 2020, The Pact on Migration and Asylum: it's never enough, never, never, ECRE Weekly Bulletin, 25 September; Maiani 2020, op.cit. 
efforts over the past years. ${ }^{39}$ Some countries, notably the Visegrád states, have already called for greater involvement of the Council and Member States in triggering and implementing the solidarity mechanism. ${ }^{40}$

Even in the presence of a strong steering mandate of the Commission, a functioning cooperation will have to rely on trust that each actor acts in good faith. However, states may lack this trust or willingness to prioritise the mechanism's functioning. Numerous Member States have already indicated their concerns over the proposal's implications. On one hand, southern European states warn that it places too large a burden on their asylum systems, with limited guarantees of support. On this basis, they have asked for the 8-month deadline before a transfer to be shortened..$^{41}$ On the other hand, Visegràd and other Eastern European states have opposed this transfer requirement outright, branding them as 'relocations through the back door'. They will likely continue seeking to evade this responsibility. ${ }^{42}$ These opposing interests may translate into implementation challenges.

For instance, EU border states benefiting from return sponsorships may not always prioritise facilitating a sponsored return. They are aware that they will cease to be responsible for these people after a certain period and may, for example, choose to prioritise returns that are non-sponsored and for which they have permanent responsibility.

As a second possible challenge, even if a benefiting state takes efforts to effectuate a return procedure seriously, sponsoring states may contest this. As the EU border state would still be responsible for the first eight months, their choices (whether to e.g. offer voluntary return, apply detention) are likely to impact the effectiveness of a return procedure. Sponsoring states may, therefore, argue that a benefiting state has not exhausted all options or is to blame for the failure to return, and object to a transfer of responsibilities on this basis.

Lastly, the procedure relies on Member States trusting the merits and safeguards of each other's return decisions and procedures. As explored in more detail below, this cannot always be expected. ${ }^{43} \mathrm{EU}$ states still have widely

39 Vignon, J. and De Brouwer, J.-L., (2020), New Pact on Migration: A balanced proposal to be further enhanced, Brussels: Jacques Delors Institute.

40 Polish Presidency of the Visegrád Group, 2020, New Pact on Migration and Asylum: Joint Position of Poland, Hungary, Slovakia, Czech Republic, Estonia, and Slovenia, Warsaw: Polish Presidency of the Visegrád Group; German Presidency of the Council of the European Union (2020), Presidency progress report on key elements of a European Migration and Asylum policy and the way forward, Berlin: German Presidency, p. 8.

41 See EUObserver, Rift widens on "returns" deadline in EU migration pact, 26 January 2021.

42 See Polish Presidency of the Visegrád Group 2020, op.cit.

43 The implementation of Directive 2001/40/EC on the mutual recognition of return decisions remains inconsistent. See European Council on Refugees and Exiles (2021), 
divergent asylum recognition rates and do not share an understanding of what countries are safe for return. ${ }^{44}$ In short, the return sponsorship mechanism is bound to lead to controversies over states' policies and the blame for bottlenecks.

Will Return Sponsorships Increase Migrants' Vulnerabilities?

The suitability of the Commission's return sponsorship proposal for the complexity and sensitivity of return policy, and its implications for migrants subject to return decisions, also merit attention. The proposal asks states to conduct negotiations with third countries on behalf of each other, recognise each other's return decisions, and facilitate return procedures. These objectives raise the question of how migrants will be treated, given the range of actors involved in the procedure. Which state actor should be held accountable when fundamental rights breaches are alleged, and multiple states and/ or EU agencies are involved? How should differences in protection standards and processes between Member States be dealt with? Lastly, how can a race to the bottom be avoided?

\subsection{The Division of Responsibilities}

As described above, the return sponsorship concept entails a complex division of responsibilities between benefiting and sponsoring states. Sponsors' level and forms of involvement will vary case by case. Their possible impact on benefiting states' policies and practices is difficult to anticipate. However, two concerns can already be mentioned. They relate to the creation of incentives to shirk responsibilities and the emergence of accountability gaps.

First, the return sponsorship's division of responsibilities may disincentivise host states from resolving a person's legal status where returns are difficult or unsustainable. Factors such as the best interest of the child, possible family ties, the length of time spent in the country ${ }^{45}$ or medical grounds have often led Member States to provide migrants with humanitarian leave to remain or

ECRE Comments on the Commission Proposal for a Regulation on Asylum and Migration Management COM2020) 610 2020/O279 (COD), Brussels: ECRE, p. 71.

44 Sundberg 2019, op.cit., p. 13 .

45 As explored in section 3.2, the return sponsorship mechanism may also apply to migrants who did not recently arrive in Europe and could therefore already have relevant links with the host country. 
other forms of regularised status. ${ }^{46}$ Return sponsorships may discourage these humane and pragmatic measures. States may simply 'wait out the clock' for migrants to be transferred elsewhere, where they may then remain in an irregular situation. ${ }^{47}$

Second, the blurring of responsibilities can weaken safeguards and accountability mechanisms for the outcomes of return. The risks associated with conducting return procedures (particularly when done quickly and in greater numbers) include violations of the principle of non-refoulement. Therefore, it is critical that responsibility for various aspects of a return procedure can be clearly and distinctly attributed to certain authorities, both legally and politically. Earlier research has highlighted that the outcome of EU return policies is already sometimes difficult to attribute, such as in the context of informal readmission agreements or Frontex involvement in returns. ${ }^{48}$ The involvement of multiple actors in return sponsorships, with formal and informal influence at various stages, risks leading to watered down responsibility, blame shifting and accountability gaps over possible human rights violations.

The question of clear responsibilities concerns most aspects of a return procedure. These include ensuring that there is no risk of abuse or chain (i.e. indirect) refoulement, seeking guarantees of protection from countries of return, establishing effective monitoring post-return, or addressing cases if a country of return disputes a migrant's nationality.

It also concerns provisions ensuring that return procedures fully comply with fundamental rights, such as in the context of a potentially disproportionate use of detention, in relation to the protection of sensitive personal data, or the right to an effective judicial remedy. Some countries have a dismal record

46 Regularisation programmes have been a regular feature of several EU Member States over the past decades, including recent schemes in the context of the coviD-19 pandemic (notably in Italy). Individual pathways to regularisation are provided in law in several Member States. See European Migration Network, 2016, EMN Synthesis Report for the EMN Focussed Study 2016. The Return of Rejected Asylum Seekers: Challenges and Good Practices, Brussels: European Migration Network, p. 33. Available at: https://ec.europa .eu/home-affairs/sites/default/files/what-we-do/networks/european_migration_net work/reports/docs/emn-studies/emn-studies-oo_synthesis_report_rejected_asylum_see kers_2016.pdf.

47 States' national grounds for granting regular status vary. As such, individuals that would receive regular status in one Member State may remain indefinitely irregular in another.

48 Sundberg Diez 2019, op.cit.; Fink, M., 2018, Frontex and Human Rights: Responsibility in 'Multi-Actor Situations' under the ECHR and EU Public Liability Law, Oxford: Oxford University Press. 
of (not) protecting migrants' rights; Hungary stands out as an extreme case, but the country is not unique. ${ }^{49}$

\subsection{Post-Transfer Protection}

A person issued a return order would typically be transferred to another Member States after eight months if returning to their country of origin or transit is not possible. This raises the question of how to guarantee their protection and access to rights after a transfer. Most of them may be unlikely to leave or be returned if returns were impossible in the first 8 months. The likelihood of conducting an effective return diminishes over time: data from several EU Member States suggests that if third-country nationals are not returned in the first few weeks, return procedures are unlikely to be successful. ${ }^{50}$ Migrants may therefore face a prolonged stay in the state they have been transferred to. This would create a challenging context. Those states with political climates most hostile to migration, and who have opposed EU relocation schemes most vehemently, may be tasked with accepting migrants who are declared to be in a state of irregularity. It also bears noting that vulnerable applicants, including children, are not explicitly exempted from return sponsorships.

More specifically, one challenge relates to third-country nationals' legal status post-transfer. After a transfer, sponsoring states could either recognise the first Member State's return decision, issue their own, or opt for a different legal status for the transferred person. ${ }^{51}$ As noted in the AMMR proposal, the articles of the Return Directive (2008/115/EC) will apply in such a case. ${ }^{52}$ However, the return sponsorship proposal does not outline in detail whether it is permitted, for example, to detain a person a second time following a transfer. If the time they may have already spent detained in another Member State is not explicitly accounted for, the overall period in detention could exceed the limits established in the Return Directive. As the Directive permits detention insofar as there is a "reasonable prospect of removal" and procedures are conducted

49 Gil-Bazo, M., 2017, The End of the Right to Asylum in Hungary?, EDAL Journal. Available at: https://www.asylumlawdatabase.eu/en/journal/end-right-asylum-hungary. For examples of problematic conditions elsewhere, see e.g.: Majcher, I., Flynn, M. and Grange, M., 2020. Immigration Detention in the European Union: In the Shadow of the 'Crisis'. Cham: Springer; Mouzourakis, M. and Pollet, K., 2018, Boundaries of Liberty: Asylum and de facto Detention in Europe, Brussels: AIDA, Available at: boundariesliberty.pdf (asylumineu rope.org).

50 European Parliamentary Research Service (2019), The proposed Return Directive (recast): Substitute Impact Assessment, PE 631.727, Brussels: E P RS, p. 115. Available at: https://www .europarl.europa.eu/thinktank/en/document.html?reference=EPRS_STU(2019)631727.

51 Interview with European Commission official, October 2020.

$5^{2}$ European Commission 2020, op.cit., Art. 58(5). 
with due diligence, it is unlikely to be legally justified and proportionate posttransfer in most cases. ${ }^{53}$ By contrast, it is conceivable that states could be especially inclined to re-apply detention following a transfer. This could be justified by the difficulties in returning that person in the first instance.

If a return procedure from the sponsoring state turns out to also not be possible, national laws will apply. This could lead to the suspension of a return decision, a toleration regime, or pathways to regularisation. ${ }^{54}$ There is very little EU harmonisation of the safeguarding of minimum standards for people who cannot be returned. ${ }^{55}$ The post-transfer situation hence merits close attention. In certain sponsoring states, risks of inadequate living conditions and situations of protracted irregularity could arise. A 2013 European Commission study found that a large number of Member States do not provide consistent access to reception, basic health care, or labour market access for migrants whose return has been indefinitely postponed. ${ }^{56}$ No EU initiatives to tackle this legislative gap are currently planned, neither in the New Pact nor the recast of the Return Directive.

Regardless of the safeguards in place, and as also noted by Francesco Maiani, the practice of transferring returnees from one state to another so they can each try to deport them is questionable. This is far removed from the "human and humane approach" that Commission President Ursula von der Leyen had touted before the New Pact's launch. ${ }^{57}$

53 European Parliament and Council of the European Union (2008), Directive 2008/115/EC of 16 December 2008 on common standards and procedures in Member States for returning illegally staying third-country nationals, Brussels, Art. 15(4). On the problems and legal challenges linked to repeated immigration detention, see Vrolijk, M.A., 2016, Immigration Detention and Non-Removability before the European Court of Human Rights, in: M.J. Guia, R. Koulish and V. Mitsilegas (Eds.), Immigration Detention, Risk and Human Rights - Studies on Immigration and Crime, Cham: Springer, pp. 47-72.

54 Interview with European Commission official, October 2020.

55 Lutz, F., 2018, Non-removable Returnees under Union Law: Status Quo and Possible Developments, European Journal of Migration and Law 2o(1), pp. 28-52. See also: European Migration Network 2016, op.cit., pp. 31-34.

$5^{6}$ European Commission, 2013, Study on the situation of third-country nationals pending return/removal in the EU Member States and the Schengen Associated Countries. HOME/2010/RFXX/PR/1001, Brussels: European Commission, pp. 33-47. Available at: https://ec.europa.eu/home-affairs/sites/homeaffairs/files/e-library/documents/policies/ irregular-migration-return/return-readmission/docs/11032013_sudy_report_on_immig ration_return-removal_en.pdf.

57 Maiani 2020, op.cit.; von der Leyen, U., 2020, State of the Union Address by President von der Leyen at the European Parliament Plenary, Brussels: European Commission, 16 September. Available at: https://ec.europa.eu/home-affairs/sites/homeaffairs/files/e -library/documents/policies/irregular-migration-return/return-readmission/docs/ 11032013_sudy_report_on_immigration_return-removal_en.pdf. 
The practice of transferring returnees will raise particular challenges for people who did not recently arrive but have been in a country irregularly for some years before being issued a return decision. The proposal applies to any "individually identified illegally staying third-country nationals" within the territory of a Member State. ${ }^{58}$ In other words, people intercepted within EU territory and subsequently issued a return order (who e.g. abscond during or after asylum procedures, eluded border controls upon entry, overstay a tourist or resident visa, or otherwise lose their legal status) could also be subjected to return sponsorship. ${ }^{59}$ In these cases, they may have already developed family and other close ties, found a residence, learnt the language and/or secured informal employment. Transferring them to another state where they may face similar situations of protracted irregularity, yet without these support networks, would only further exacerbate vulnerabilities.

In sum, these concerns render the return sponsorship mechanism in the New Pact too blunt a tool to address the complex circumstances of a significant portion of people who are issued return decisions but have weak prospects for return. ${ }^{60}$

\section{4 Will Third Countries Cooperate More on Return and Readmission?}

Closer cooperation with third countries is at the centre of the Commission's concept on return sponsorship. In order to function coherently and fulfil its political rationale, the return sponsorship concept relies on returns being conducted in far larger numbers and much more quickly. If this is not achieved, the issue of migrants' transfer to other EU Member States will become central to the proposal's functioning in practice. As described in the preceding sections, such transfers would not be without concerns. In several interviews with

58 European Commission 2020, op.cit. Also interview with European Commission official, December 2020.

59 There are no official figures on the profiles of people issued return orders, or the length of their prior stay in the country. Visa overstayers, for example, are estimated to constitute a significant proportion of the people irregularly in Europe. See Morehouse, C. and Blomfield, M., 2011, Irregular Migration in Europe, Washington, D.C.: Migration Policy Institute. Available at: https://www.migrationpolicy.org/research/tcm-irregular-migration-europe.

6o It is estimated that there are at least 300,00o "non-removable returnees" in Europe per year. See European Commission (2019), Commission Staff Working Document: Fitness Check on EU Legislation on legal migration $\{\operatorname{SwD}(2019) 1056$ final $\}, \operatorname{SWD}(2019) 1055$ final, Brussels: European Commission, p. 85. Available at: https://ec.europa.eu/transparency/ regdoc/?fuseaction=list\&coteId=10102\&year=2019\&number=1055\&version=ALL\&langua ge $=$ en. 
the authors, EU officials stated that they should remain the exception. ${ }^{61}$ Low returns would also heighten the pressure on countries of first arrival, reignite sensitive discussions on responsibility-sharing in Europe and blame for bottlenecks in EU return systems, and exacerbate questions over the protection and inclusion of migrants with low return prospects.

It will not be easy for the EU to increase the number of effectuated returns significantly. As highlighted above, in 2019, the number of returns carried out was less than a third of the total issued return orders. This figure has consistently ranged between $30 \%$ to $40 \%$ in recent years. ${ }^{62}$ Increasing returns beyond current levels is far from simple. For instance, the return of many migrants with an order to leave risks compromising the principle of non-refoulement. EU Member States have issued many return decisions for nationals of countries that struggle with insecurity and conflict, including Afghanistan, Mali and Iraq. EU Member States often cite the existence of safe areas within these countries as an argument as to why returns are possible. However, this argument is contested. ${ }^{63}$ Returns to these states, or states like Turkey that pose a risk of indirect (or secondary) refoulement, have faced legal challenges across the EU. ${ }^{64}$

A further challenge to the Commission's objective is securing closer readmission cooperation from non-EU countries. Countries of origin tend to benefit from the remittances sent by citizens who managed to migrate to Europe or elsewhere, even when they reside in irregular situations and/or work in the informal economy. Close cooperation with the EU on return issues is therefore often perceived by countries of origin to contradict - even betray - their populations' interest and can carry high political costs. ${ }^{65}$ The case for forced

61 Interviews with European Commission officials, October and November 2020.

62 See Eurostat, Third country nationals returned following an order to leave - annual data (rounded)[migr_eirtn] (accessed 16 December 2020); Eurostat, Third country nationals ordered to leave - annual data (rounded)[migr_eiord] (accessed 16 December 2020).

63 For instance, see the UN Refugee Agency's assessment of the availability of 'Internal Protection Alternatives' in Kabul, UN High Commissioner for Refugees, 2019, Afghanistan: Compilation of Country of Origin Information (COI) Relevant for Assessing the Availability of an Internal Flight, Relocation or Protection Alternative (IFA/IRA/IPA) to Kabul, Geneva: UNHCR. Available at: https://www.refworld.org/country,UNHCR,,AFG „5 def56204,o.html.

64 This can occur, for example, because EU asylum procedures under the Qualification Directive (2011/95/EU) do not consider all grounds that could amount to refoulement, and because individuals who would face persecution if returned may be refused international protection on procedural or technical grounds. This is the case for a non-trivial proportion of rejected applications. For further detail, see Sundberg Diez 2019, op.cit.

65 Zanker, F. and Altrogge, J., 2019, Why return from Europe is causing problems for The Gambia, The Conversation, 18 November. Available at: https://theconversation.com/why -return-from-europe-is-causing-problems-for-the-gambia-124036. 
returns or returns of non-nationals has become particularly contentious, contributing to the long delays in reaching an agreement on the 'Post-Cotonou' agreement between the EU and the Organisation of African, Caribbean and Pacific States. ${ }^{6}$ For example, public backlash pushed Mali to withdraw from an agreement with the EU in 2016. More generally, it often leads third states to refuse to sign formal readmission agreements with the Union. ${ }^{67}$ Readmission can also be costly due to the structural and institutional reforms needed to implement formalised agreements or (re)integrate returnees.

In the New Pact, the Commission proposes strengthening third countries' cooperation by having stronger incentives and more negative conditionality. Member states are likely to follow the Commission's proposal to expand the EU's toolbox. They may agree to introduce a special clause on the possibility of sanctioning non-cooperative behaviour, as proposed in the AMMR proposal, and may endorse the calls for comprehensive partnerships with third countries. ${ }^{68}$ However, whilst political agreement could come swiftly, some hesitance in operationalising such tools in follow-up is to be expected. This section discusses whether (i) this approach can deliver on the Commission's heightened expectations; and (ii) Member States will be willing to implement it in practice.

\subsection{The Effectiveness of Conditionalities}

First, the effectiveness of using conditionality to increase readmission cooperation cannot be taken for granted. On the one hand, regarding negative conditionality, the Commission conducted an impact assessment in 2018 alongside the revised Visa Code, which further legalised the conditionality link between readmission cooperation and visa benefits. The Commission concluded that "there is no hard evidence on how visa leverage can translate into better cooperation of third countries on readmission", besides limited "anecdotal experience". ${ }^{69}$

Bangladesh and Côte d'Ivoire are two countries often referred to by proponents of a punchier EU approach. The threat of visa restrictions seemingly

66 See Boidin, J-C., 2O2O, ACP-EU relations: The end of preferences? A personal assessment of the Post-Cotonou agreement, ECDPM, December. Available at: https://ecdpm.org/publica tions/acp-eu-relations-end-preferences-personal-assessment-post-cotonou-agreement/.

67 Mercator Dialogue on Asylum and Migration 2020, op.cit., Ch. 3-4.

68 European Commission 2020, op.cit., Art. 7 .

69 European Commission, 2018, Commission Staff Working Document Impact Assessment Accompanying the document Proposal for a Regulation of the European Parliament and of the Council amending Regulation (EC) No 810/2009 establishing a Community Code on Visas (Visa Code), $S W D(2018) 77$ final, Brussels: EC, p. 31. 
led to their acceptance of readmission arrangements in September 2017 and July 2018, respectively. ${ }^{70}$ However, in the Bangladeshi case, the return rate has only fallen further since, whereas it has barely increased for Côte d'Ivoire. ${ }^{71}$ While readmission cooperation is influenced by a complex range of factors, ranging from the state of overall bilateral relations to shifts in competing domestic priorities, these cases highlight the need to examine carefully whether negative conditionalities are indeed effective. The EU seems to put too much hope into formal and informal readmission agreements even if these agreements rarely lead to higher return numbers if viewed from a more longitudinal perspective. ${ }^{72}$

Conversely, regarding positive conditionality, a successful example is the Western Balkans. All countries from this region (barring Kosovo) were offered visa-free travel to Europe in exchange for close cooperation on readmission and other areas. This was a yearlong process, involving an ever-increasing list of EU conditions and close monitoring on the EU's side. Since 2011, the EU has also created a visa suspension mechanism, threatening the reintroduction of visa requirements in case of a lack of cooperation. It was first tailor-made to the Western Balkans but was reformed in 2016 to be applied more widely. ${ }^{73}$ The Western Balkans have had very high return rates from the EU, even reaching over $100 \%$ in some years (due to backlogs). ${ }^{74}$

However, the Western Balkans constitute a relatively unique setting: it is geographically close to the EU and keen to have close political relations (reflected by the EU accession process). Importantly, the EU has also been ready to provide them with strong incentives; not only visa facilitation but full visa-free travel. Geographical proximity, strong incentives and close political relations

70 Council of the European Union 2019, op.cit., p. 6; Peel, M., 2018, EU threatens visa curbs over illegal migrant returns, Financial Times, 14 March. Available at: https://www.ft.com/ content/eba94efa-2783-11e8-b27e-cc62a39d57ao.

71 In 2017, 11.1\% of all nationals from Bangladesh and 2.7\% from Côte d'Ivoire who were ordered to leave their host country were returned from the EU27. In 2019, these figures were $8.6 \%$ for Bangladesh and $3.4 \%$ for Côte d'Ivoire. See Eurostat, Third country nationals returned following an order to leave - annual data (rounded)[migr_eirtn] (accessed 16 December 2020); Eurostat, Third country nationals ordered to leave - annual data (rounded)[migr_eiord] (accessed 16 December 2020).

72 See Stutz, P and Trauner, F., 2021, The EU's return rate with third countries: why EU readmission agreements do not make much difference. International Migration, https://doi .org/10.1111/imig.129o1.

73 Another example is Turkey, which agreed to the EU-Turkey Statement in 2016. Moving towards visa-free travel was defined as an incentive for Turkey to accept the return of migrants from Greece. See Trauner, F. 2017), The EU Visa Suspension Mechanism, Paris: European Union Institute for Security Studies.

See Stutz and Trauner 2021, op.cit. 
are factors that will most likely to lead to cooperation on readmission. ${ }^{75}$ Transposing this success elsewhere is not straightforward.

Lastly, it bears noting that convincing third countries to engage on readmission may prove more challenging if return sponsorships are fully operational. States may become more reluctant to sign readmission agreements if those agreements can act as the basis for returns from across the Union's territory.

\subsection{Having Conditionality Tools - and Using Them}

Therefore, if conditionality is to overcome third countries' objections to readmission effectively, the EU's offers may need to be substantial. However, it is not certain that Member States will be ready to commit to a strong conditionality or prioritise readmission cooperation over other relevant policy areas. The political will of Member States will largely determine the extent to which conditionality is effectively employed. This willingness has been lacking in the past. Different trade-offs will need to be weighed regarding the use of positive and negative incentives.

Firstly, particularly for positive conditionality, Member States may be unwilling to facilitate visa travel or open up access to their labour market to sufficient degrees. On the one hand, visa policies are sensitive for Member States; they are perceived as a useful tool to prioritise migration from one region over another. Moreover, several governments face pressures from populist parties and want to avoid being portrayed as lenient on migration issues by opening visa channels to countries associated with irregular migration. ${ }^{76}$ The EU has thus far refrained from offering similarly strong incentives to non-European countries as it did to the Western Balkans. In negotiations with Morocco and Tunisia, this led discussions to stall, ${ }^{77}$ with readmission and visa facilitation negotiations with Morocco hitting further obstacles in late 2020.78

A further substantial incentive concerns labour pathways. The Commission already pushed for creating legal migration quotas in the form of EU Mobility Partnerships in the late 20oos. However, Member States retain the competence

75 Cassarino, J.-P., 2010, Readmission Policy in the European Union, PE 425.632, Brussels: European Parliament. Available at: https://op.europa.eu/en/publication-detail/-/publi cation/b8111d18-cbfc-4d72-8554-d85e86boeff3/language-en.

76 See Trauner, F. and Manigrassi, E., 2014, When Visa-free Travel Becomes Difficult to Achieve and Easy to Lose: The EU Visa Free Dialogues after the EU's Experience with the Western Balkans, European Journal of Migration and Law, Volume 16, Issue 1, pp. 125-145.

77 Abderrahim, T., 2019, A Tale of Two Agreements: EU Migration Cooperation with Morocco and Tunisia, Barcelona: European Institute of the Mediterranean.

78 See Reuters, 2020, Morocco rebuffs EU request to re-admit third-country migrants, 15 December 2020. Available at: https://www.reuters.com/article/morocco-eu-migration -int-idUSKBN28P252. 
over defining national entry quotas and have not yet shown much political will to use these as an incentive. ${ }^{79} \mathrm{~A}$ case in point is the EU's Mobility Partnership with Morocco, which was signed in 2013. ${ }^{80}$ In 2010, 10,416 Moroccan seasonal workers were allowed to enter the EU. By 2016, the number fell to 3,781, despite the Mobility Partnership in place. Member states were unwilling to offer more places. ${ }^{81}$ In the coming years, Member States may face a difficult economic context due to the COVID-19 pandemic. They may not be willing to increase third-country nationals' access to their labour markets.

Secondly, for negative conditionality, Member States would need to act in unison and prioritise migration-related issues in Europe's foreign policymaking. EU governments may be reluctant to accept the impositions of visa or economic sanctions against a valued partner only due to missing cooperation on return. Some EU Member States have close socioeconomic and political ties with countries of migrants' origin and transit (often post-colonial). They cooperate closely on a whole range of economic, foreign and security issues (e.g. Spain - Morocco; Italy - Tunisia; France - Mali). For instance, France is leading a wider European effort to fight Islamic terrorism in Sahel states - efforts considered vital to the security of both African and European states. States may be unwilling to jeopardise these broader interests for readmission. ${ }^{82}$ At times, EU Member States have also gone for bilateral readmission agreements instead of supporting the negotiations of EU readmission ones. ${ }^{83}$ This suggests that the appetite for prioritising an EU-wide return ecosystem over individual partnerships may be small.

Representatives of several non-EU countries have already clearly stated their opposition to such an approach of negative conditionality. ${ }^{84}$ The Commission's

79 Reslow, N., 2018, Making and Implementing Multi-Actor EU External Migration Policy: the Mobility Partnerships, in: Sergio Carrera, Leonhard Den Hertog, Marion Pamozzon and Dora Kostakopoulou (eds.), EU External Migration Policies in an era of global mobilities: intersecting policy universes, Leiden: Brill | Nijhoff.

8o Council of the European Union, 2013, Joint declaration establishing a Mobility Partnership between Morocco and the European Union and its Member States, 6139/13, Brussels: CE. Available at: https://data.consilium.europa.eu/doc/document/ST-6139-2013 -ADD-1-REV-3/en/pdf.

81 Guild, E., 2020, Negotiating with Third Countries under the New Pact: Carrots and Sticks?, Immigration and Asylum Law and Policy Blog, 27 November. Available at: http:// eumigrationlawblog.eu/negotiating-with-third-countries-under-the-new-pact-carrots -and-sticks/.

82 Cassarino 2020, op.cit., p. 4.

83 Panizzon, M., 2012, Readmission agreements of EU Member States: a case for EU subsidiarity or dualism?, Refugee Survey Quarterly, Volume 31, Issue 4, pp. 101-133.

84 Comment by Ambassador Teneng Mba Jaiteh, Head of Mission of The Gambia to the EU, during Return and readmission after the New Pact online event as part of the Mercator 
Communication accompanying the New Pact's proposals also acknowledges that readmission cooperation can be "politically sensitive for partners". ${ }^{85}$ In short, the costs of a conditionality approach to a long-term partnership based on mutual trust and shared interests may be considerable. The willingness of Member States to use - and risk - their close bilateral ties with third countries will be a determining factor of whether the $\mathrm{EU}$ (as a whole) manages to realise a more conditionality-driven EU approach on returns.

More generally, the EU must now also deal with a quickly shifting international landscape. Its policy offers - and demands - are in increasing competition with other global players, notably in the African continent, where Chinese, Russian, American and Middle Eastern actors are investing in and competing for influence. The altering international context may make it more complicated for the EU to engage with negative conditionalities in the return domain and produce further hesitation for Member States.

This article draws five conclusions from an analysis of the New Pact's return sponsorship concept. To begin with, the concept of return sponsorship is an instrument deriving from realpolitik thinking, aimed at bridging divides over responsibility-sharing and the EU-wide distribution of migrants. However, it risks only shifting, rather than ending, these conflicts. Questions over the precise modes of mandatory solidarity contributions, particularly the requirement to transfer migrants in irregular situations after eight months, have already proven controversial. The instrument has been too far-reaching for some, and too slow and insufficiently committing for others. EU negotiations are likely to remain politicised, even if the focus has changed.

Second, the Commission's proposed solidarity mechanism is defined by the flexibility it grants Member States to contribute to the overall functioning of a pan-European migration system in tailor-made ways, in line with their preferences. This flexibility comes at the expense of predictability for EU border states facing migratory pressure. If accepted, the proposal could provide greater European responsibility-sharing than ensured in the status quo. However,

Dialogue on Asylum and Migration project on 21 October 2020, Brussels: European Policy Centre. Available at: https://www.epc.eu/en/events/Return-and-readmission-after -the-New-Pact $\sim 37$ cb34.

85 European Commission, 2020, Communication from the Commission to the European Parliament, the Council, the European Economic and Social Committee and the Committee of the Regions on a New Pact on Migration and Asylum, Сом(2020)6og final, p. 17. 
overall, it constitutes a limited corrective mechanism with few enforcement tools. It may thus do little to alleviate the pressure on EU border states.

Third, the Commission is looking to ensure that solidarity contributions match states' needs. However, this system is highly complex from an administrative and operational point of view. It entails, for example, a network of bilateral coordination facilitated by a yet-to-be-appointed EU Return Coordinator who will have to smooth tensions and avoid the politicisation of the concept of return sponsorship. These will clearly be challenging tasks. Moreover, the systematic process of bilateral coordination and negotiations risks providing cooperation-reluctant Member States with opportunities to shirk and shift responsibilities. Overall, the solidarity mechanism, notably the return sponsorship concept, may struggle to deliver tangible and predictable results.

Fourth, the return sponsorship mechanism is ill-suited to respond to the human rights risks involved in return procedures. Rather, it may create new vulnerabilities for migrants ordered to leave. Particularly the proposed transfer to a sponsoring state after eight months requires additional safeguards. Particular attention needs to be paid to the situation of migrants unlikely to leave or to be returned. The proposal is silent on their post-transfer protection or prospects, assuming primarily that returns will eventually succeed in all but exceptional cases.

Fifth, return sponsorships rely on returns to non-EU countries increasing in an unprecedented manner. For the last two decades, many third countries have been highly reluctant to readmit their nationals, given the role of migration in their political economies. They may not adapt their behaviour quickly, even if the EU changes its approach. The strategy proposed by the New Pact is to increase the use of conditionality. However, the EU's conditionality approach tends to be successful only in very particular circumstances (notably if a third country is keen to get closer political relations and the EU has strong, positive incentives to offer). These preconditions will be difficult to replicate in many regions. At the same time, it remains to be seen if EU Member States will have the political will to employ sanctioning and negative conditionalities. There are tight political and economic trade-offs that Member States will need to keep in mind, and that may constrain Europe's options.

If the approach to the external dimension does not change and returns are not stepped up in an unprecedented manner, the internal transfers of returnees within Europe will come to the forefront, gaining more relevance than the Commission currently plans for. This will also heighten politically sensitive discussions around the internal dimension of the return sponsorship mechanisms and, with them, on responsibility-sharing in Europe more generally - the very challenge the Pact sought to address. 
The European Commission is taking a considerable political risk with the proposed solidarity mechanism, and particularly the return sponsorship concept. It is an instrument of high stakes, and potentially only low gains. The stakes are high for EU border countries, whose asylum systems may continue to endure stress; for the discussion on the EU's problem-solving capacity and European solidarity, which may remain politicised; for migrants subject to return decisions, whose protection may prove uncertain; and for relations with countries of migrants' origin, which may see migration become an increasingly determining element of their cooperation with the Union, contrary to their interests. Meanwhile, as the five conclusions above highlight, the potential gains are modest. Return sponsorships may not become a game-changer with regard to correcting the disproportionate pressure on countries at the EU's border or enhancing returns to third countries. 